\title{
Pemanfaatan Sensor CCD dan Interferometer Michelson untuk Menentukan Koefisien Difusi Larutan Transparan
}

\author{
Retna Apsari,* Trisnaningsih, dan Umi Salamah \\ Jurusan Fisika FMIPA, Universitas Airlangga \\ Kampus C Unair, Jl. Mulyorejo, Surabaya
}

\begin{abstract}
Intisari
Telah dilakukan penelitian untuk menentukan nilai koefisien difusi larutan transparan ammonium dihidrogen phosphate $\left(\mathrm{NH}_{4}\right) \mathrm{H}_{2} \mathrm{PO}_{4}$ menggunakan interferometer Michelson. Perubahan rumbai pada waktu-waktu tertentu diakibatkan oleh perbedaan beda lintasan optis karena perbedaan konsentrasi larutan yang diamati dengan sensor CCD (kamera digital). Perbedaan lintasan optis dihitung dengan mengukur jarak dua pusat rumbai pada waktu yang berbeda. Nilai koefisien difusi yang dihasilkan untuk konsentrasi 0,$4981 ; 0,7469 ; 0,9959$; 1,$5471 ; 1,9907 \mathrm{gmol} / \ell$ masing-masing sebesar $(8,66 \pm 0,03) \cdot 10^{-6} ;(8,09 \pm 0,07) \cdot 10^{-6} ;(7,28 \pm 0,10) \cdot 10^{-6}$; $(6,70 \pm 0,06) \cdot 10^{-6} ;(5,57 \pm 0,01) \cdot 10^{-6} \mathrm{~cm}^{2} / \mathrm{s}$. Hasil penelitian menunjukkan bahwa sensor CCD kamera dapat digunakan untuk mengamati perubahan rumbai yang menunjukkan perbedaan beda lintasan optis. Interferometer Michelson dapat digunakan untuk menentukan nilai koefisien difusi larutan transparan dan hasilnya sesuai literatur.

KATA KUNCI: koefisien difusi, interferometer Michelson, $\left(\mathrm{NH}_{4}\right) \mathrm{H}_{2} \mathrm{PO}_{4}$, sensor CCD
\end{abstract}

\section{PENDAHULUAN}

Salah satu eksperimen yang penting untuk menentukan difusitas adalah teknik interferensi optis [1]. Jenis interferometer yang cukup dikenal adalah interferometer Michelson. Interferometer Michelson merupakan contoh perangkat optik eksperimen interferensi yang bisa diaplikasikan untuk menentukan nilai koefisien difusi suatu larutan berdasarkan pengamatan pergeseran fase yang terekam pada rumbai, dengan menggunakan laser He Ne sebagai sumber cahaya. Keunggulan dari metode Interferometer Michelson ini adalah adanya hasil pergeseran dua rumbai yang mengindikasikan pergeseran titik-titik ekstrim, yang dapat menunjukkan perbedaan beda lintasan optis. Dengan memperhatikan pergeseran rumbai terhadap fungsi waktu, maka nilai koefisien difusi larutan transparan dapat ditentukan. Pengukuran jarak pergeseran rumbai saat berlangsungnya proses difusi belum dapat diamati pada penelitian sebelumnya [2].

Salah satu aplikasi interferometer Michelson adalah untuk menentukan nilai koefisien difusi larutan transparan berdasarkan pengamatan pergeseran fase secara digital, yang dalam hal ini peneliti menggunakan sistem difusi ammonium dihidrogen phosphate $\left(\mathrm{NH}_{4}\right) \mathrm{H}_{2} \mathrm{PO}_{4}$, dikarenakan sistem difusi tersebut lebih peka terhadap cahaya dibandingkan dengan penelitian sebelumnya [3], harga terjangkau serta sampel tidak rusak oleh laser He-Ne.

Dalam penelitian ini, pengamatan pergeseran rumbai memanfaatkan sensor CCD yang terdapat pada kamera digital merk PIXELS (6.6 Mpixels image files), dengan resolusi sebesar 2976 x 2232 pixels. Sensor CCD tersebut dapat menangkap fenomena yang terbentuk. Dari hasil rum-

*E-MAIL: apsari.zara@lycos.com bai dapat diamati pergeseran rumbai, yang disebabkan karena perbedaan konsentrasi pada waktu-waktu tertentu. Perbedaan beda lintasan optis dapat dilihat dari selisih jarak pergeseran rumbai antara pusat dua rumbai pada waktu-waktu tertentu. Pergeseran rumbai tersebut eqivalen dengan pergeseran titiktitik ekstrim dari waktu ke waktu selama terjadinya proses difusi. Keunggulan dari sensor CCD pada kamera digital ini adalah dapat memberikan pengamatan dengan resolusi yang tinggi.

Penelitian tentang penentuan nilai koefisien difusi larutan sudah beberapa kali dilakukan, dengan metode lain dan jenis sampel yang lain, yaitu dengan metode interferometri holografi dengan sampel sistem terner oleh Apsari dkk. [3]. Dalam penelitian tersebut sistem difusi yang dipakai adalah sistem difusi terner yang kurang peka terhadap cahaya. Metode tersebut masih membutuhkan kerja maksimal di laboratorium untuk mendapatkan nilai koefisien difusi larutan transparan, kemudian muncul penyempurnaan untuk metode interferometri holografi tersebut dengan analisis rumbai secara digital dari rekonstruksi digital dengan bantuan teknik pemfilteran [4]. Sistem difusi yang digunakan adalah sama-sama larutan encer, namun dalam perkembangannya dibutuhkan suatu larutan encer yang lebih peka terhadap cahaya seperti ammonium dihidrogen phosphate yang dipakai pada penelitian ini. Dengan alasan yang telah disebutkan di atas, dibutuhkan suatu metode penentuan koefisien difusi larutan transparan yang lebih sederhana, lebih mudah dilakukan, dengan menggunakan sensor kamera CCD yang terjangkau, dan bisa menentukan perbedaan lintasan optis yang disebabkan karena perbedaan konsentrasi pada waktu-waktu (t) tertentu. Selisih pergeseran rumbai yang eqivalen dengan pergeseran titik-titik ekstrim inilah yang sebenarnya diamati dalam penelitian ini, dan selanjutnya digunakan untuk menentukan nilai koefisien difusi larutan transparan. 


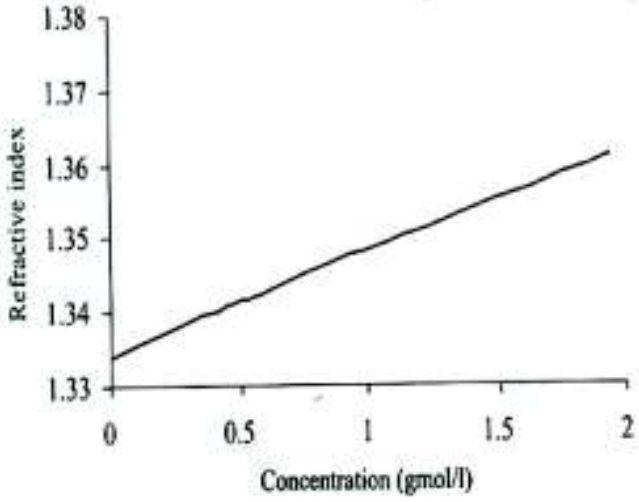

Gambar 1: Perubahan indeks bias terhadap konsentrasi

\section{DASAR TEORI}

Dari hukum Fick II tentang difusi, diasumsikan difusi larutan encer 1 dimensi ke arah sumbu-z dengan konsentrasi $\mathrm{C}(\mathrm{x}, \mathrm{t})$ memenuhi :

$$
\frac{\partial C(z, t)}{\partial t}=D \frac{\partial^{2} C(z, t)}{\partial x^{2}}
$$

dengan D adalah koefisien difusi, dan $\mathrm{C}(\mathrm{z}, \mathrm{t})$ adalah konsentrasi pada posis z waktu t. Menurut Crank (1970), dalam 1D penyelesaian Pers.(1) untuk campuran larutan biner mulamula $(\mathrm{t}=0)$ yang dipisahkan pada $\mathrm{z}=0$ dengan konsentrasi
$\mathrm{C}_{1}$ dan $\mathrm{C}_{2}$ adalah

$$
C(z, t)=\frac{C_{1}+C_{2}}{2}+\frac{\left(C_{1}-C_{2}\right) \pi}{2 \sqrt{2}} \operatorname{erf}\left(\frac{z}{2 \sqrt{D t}}\right)
$$

dengan erf(u) sebagai fungsi ralat:

$$
\operatorname{erf}(u)=\frac{2}{\sqrt{\pi}} \int_{0}^{u} \exp \left(-t^{2}\right) d t
$$

$\mathrm{C}_{1}$ dan $\mathrm{C}_{2}$ adalah konsentrasi mula-mula dua larutan, dan $\mathrm{D}$ diandaikan tetap. Untuk difusi sel dengan variabel konsentrasi yang rapat, maka indeks bias berubah secara linear dengan konsentrasi (seperti pada Gambar 1), n sebagai fungsi z untuk waktu yang berbeda-beda akan mempunyai formulasi yang sama dengan Pers.(4). Perubahan indeks bias sebagai fungsi $\mathrm{z}$ untuk interval waktu $\Delta \mathrm{t}$ adalah:

$$
\Delta n(z, \Delta t)=m C(z, t)+n_{\circ}
$$

dengan $\mathrm{m}$ adalah gradien kurva antara konsentrasi dan indeks bias berdasarkan penambahan variasi konsentrasi yang ditambahkan pada sel, dan $\mathrm{n}_{\circ}$ adalah konstan, fungsi itu ditampilkan pada Gambar 2. Plot tersebut menggunakan nilai konsentrasi yang digunakan pada eksperimen ini yaitu $C_{a v g}=\frac{C_{1}+C_{2}}{2}=$ $1,5461 \mathrm{gmol} / \ell$.

Ada perubahan indeks bias pada arah tegak lurus arah difusi terhadap waktu. Perubahan ini adalah perubahan indeks bias untuk dua perbedaan waktu $\mathrm{t}_{1}$ dan $\mathrm{t}_{2}$ yang diberikan oleh persamaan:

$$
\Delta n\left(z, t_{1}, t_{2}\right)=n\left(z, t_{2}\right)-n\left(z, t_{1}\right)=m \frac{C_{1}-C_{2}}{2}\left[\operatorname{erf}\left(\frac{z}{2 \sqrt{D t_{2}}}\right)-\operatorname{erf}\left(\frac{z}{2 \sqrt{D t_{1}}}\right)\right]
$$

Plot Pers.(5) ditunjukkan pada Gambar 3 untuk dua interval waktu (30-45) dan (30-360) menit, dan plot tersebut mempunyai dua nilai ekstrim masing-masing $\mathrm{z}_{c 1}$ dan $\mathrm{z}_{c 2}$. Posisi ini dapat ditentukan dari kondisi :

$$
\frac{d}{d z} \Delta n\left(z, t_{1}, t_{2}\right)=0
$$

Dengan menggunakan Pers.(6), Pers.(5) dan Pers.(3) untuk fungsi error dari nilai ekstrim dapat ditulis :

$$
\begin{aligned}
z_{c_{1}} & =\sqrt{\frac{2 D \ln \left(t_{2} / t_{1}\right)}{\left(1 / t_{1}\right)-\left(1 / t_{2}\right)}} \\
z_{c_{2}} & =-\sqrt{\frac{2 D \ln \left(t_{2} / t_{1}\right)}{\left(1 / t_{1}\right)-\left(1 / t_{2}\right)}}
\end{aligned}
$$

Pengurangan $Z_{c 2}$ dari $Z_{c 1}$ akan dipisahkan oleh dua nilai ek- strim d:

$$
d=2 \sqrt{\frac{2 D \ln \left(t_{2} / t_{1}\right)}{\left(1 / t_{1}\right)-\left(1 / t_{2}\right)}}
$$

Kemudian koefisien difusi larutan didefinisika sebagai :

$$
D=\frac{d^{2}\left[\left(1 / t_{1}\right)-\left(1 / t_{2}\right)\right]}{8 \ln \left(t_{2} / t_{1}\right)}
$$

Dari Gambar 2 dapat dilihat setelah 150 menit proses difusi maka indeks bias pada sel difusi adalah konstan, sehingga sangat memungkinkan untuk memunculkan pola interferensi secara serentak. Perbedaan indeks bias yang datang pada bidang yang berbeda pada sel dan cahaya yang melaluinya akan menyebabkan adanya perbedaan jejak lintasan optis yang berbeda, dan diberikan menurut persamaan:

$$
\Delta_{1}\left(z_{1}\right)=n_{1}\left(z_{1}\right) L, \Delta_{2}\left(z_{2}\right)=n_{1}\left(z_{2}\right) L, \cdots
$$

dengan $\Delta$ adalah beda jejak lintasan optik antara dua sinar laser yang melalui bidang sel pada $\mathrm{z}_{1}, \mathrm{z}_{2}, \ldots$ dan $\mathrm{n}_{1}, \mathrm{n}_{2}$, 


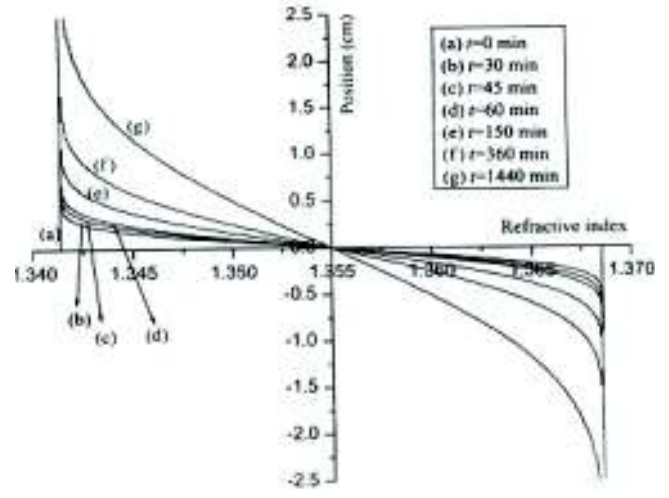

Gambar 2: Variasi indeks bias terhadap posisi

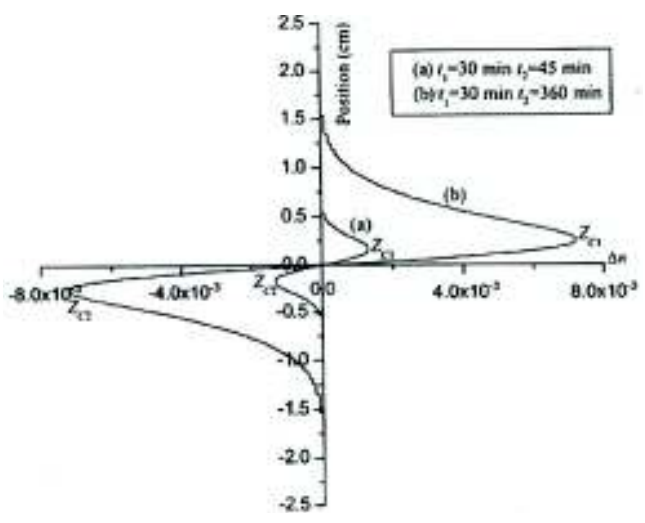

Gambar 3: Perubahan dalam $\Delta n$ terhadap posisi

.... adalah kebergantungan indeks bias pada bidang sel, dan L adalah ketebalan sel. Sejak beda lintasan optis melelui bidang yang berbeda, maka indeks bias akan berubah bergantung waktu. Pola interferensi berupa rumbai yang terbentuk juga akan bergeser dengan waktu. Pergeseran rumbai akan eqivalen dengan pergeseran titik-titik ekstrim, $\mathrm{z}_{c 1}$ dan $\mathrm{z}_{c 2}$ (Gambar 4). Ketika proses difusi berjalan terhadap waktu, karakteristik titik-titik ekstrim akan bergeser menjauh terhadap waktu sampai pola interferensi kedua rumbai terbentuk. Penghitungan koefisien difusi larutan didasarkan pada pengukuran jarak pergeseran rumbai antara pusat pusat-pusat kedua pola rumbai pada interferogram pada waktu $t_{1}$ dan $t_{2}$. Nilai $d$ kemudian disubstitusi pada Pers.(9) untuk mendapatkan nilai koefisien difusi larutan.

\section{METODOLOGI PENELITIAN}

Bahan yang digunakan dalam penelitian ini adalah larutan ammonium dihidrogen phosphate $\left(\mathrm{NH}_{4}\right) \mathrm{H}_{2} \mathrm{PO}_{4}$, dengan berbagai konsentrasi $(0,4981 ; 0,7469 ; 0,9959 ; 1,5471 ; 1,9907$ gmol/ $\ell$ ). Variabel penelitian yang dicari adalah $\mathrm{d}_{1}, \mathrm{~d}_{2}, \Delta d$ $=\left(d_{2}-d_{1}\right), t_{1}$ dan $t_{2}$. Rumus yang digunakan untuk mendapatkan nilai koefisien difusi larutan transparan berdasarkan
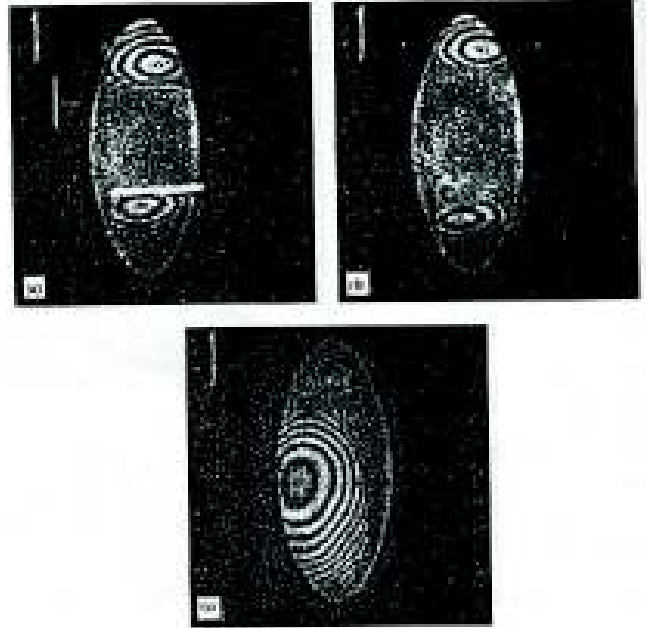

Gambar 4: Perubahan rumbai interferensi terhadap waktu pada konsentrasi Rata-rata 0,4981 gmol/ $\ell$ (a). setelah 30 menit, (b). setelah 90 menit, (c). keseimbangan [1]

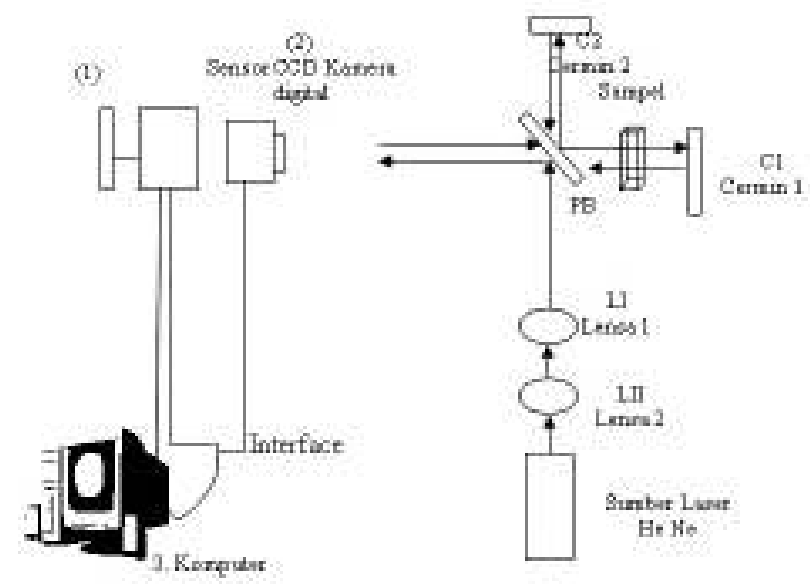

Gambar 5: Susunan alat penelitian

pengamatan pergeseran seperti pada Pers.(9).

Prosedur kerja penelitian adalah sebagai berikut: menyusun alat eksperimen seperti pada Gambar 5, dengan menghubungkan kabel USB mini yang berfungsi sebagai interface dari kamera digital ke komputer. Menempatkan sel sampel (gelas sampel) yang telah berisi aquades pada salah satu lengan interferometer Michelson. Setelah susunan peralatan tersusun dengan baik, dilanjutkan dengan mencari bentuk rumbai sebelum dan sesudah proses difusi dan memfotonya. Pengambilan data dilakukan dengan melakukan variasi konsentrasi dengan menggunakan pipet tetes untuk menetesi aquades di gelas sampel dengan ammonium dihidrogen phosphate $\left(\mathrm{NH}_{4}\right) \mathrm{H}_{2} \mathrm{PO}_{4}$ dengan nilai variasi yang ditentukan. Pada saat tetesan pertama dicatat sebagai fungsi waktu $(t=0)$. Setelah terjadi proses difusi dan waktu telah berjalan 30 menit pertama, maka rumbai 


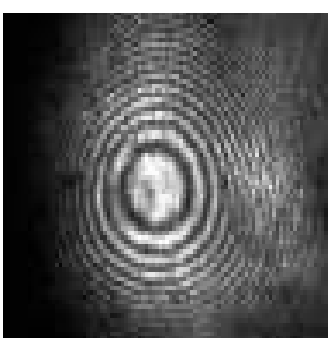

(a)

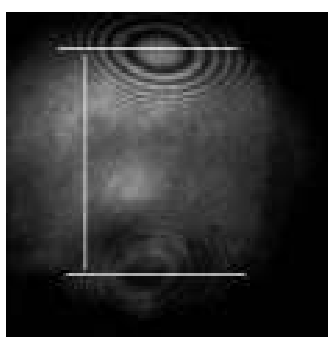

(b)

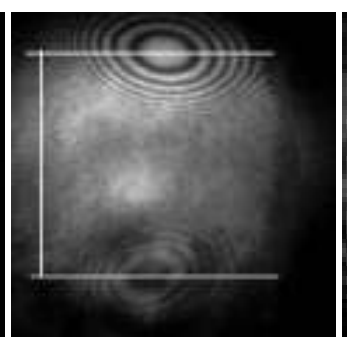

(c)

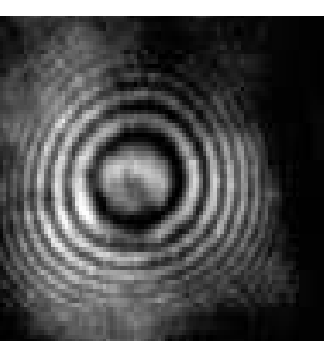

(d)

Gambar 6: Perubahan gambar rumbai pada konsentrasi 0,4981 gmol/ $\ell$ untuk waktu-waktu tertentu (a). Gambar rumbai sebelum proses difusi pada waktu $t_{\circ}=0$ detik, (b). Gambar rumbai yang terbentuk saat proses difusi berlangsung pada waktu $\mathrm{t}_{1}=30$ menit atau $1800 \mathrm{dtk}$, (c). Gambar rumbai yang terbentuk saat proses difusi berlangsung pada waktu $t_{2}=90$ menit atau $5400 \mathrm{dtk}$, (d). Gambar rumbai yang terbentuk setelah proses difusi berakhir pada $t_{3}>5400$ detik.

TABEL I: Nilai koefisien difusi larutan transparan dari literature

\begin{tabular}{lccccc}
\hline \hline $\begin{array}{l}\text { Konsentrasi } \\
(\mathrm{gmol} / \ell)\end{array}$ & $\begin{array}{c}\text { Nilai Koefisien Difusi } \\
\text { Larutan Transparan Hasil } \\
\text { penelitian }\left(\mathrm{x} \mathrm{10} \mathrm{cm}^{-6} / \mathrm{s}\right)\end{array}$ & $\begin{array}{c}\text { Chhaniwal dkk } \\
\left(\mathrm{x} 10^{-6} \mathrm{~cm}^{2} / \mathrm{s}\right)[1]\end{array}$ & $\begin{array}{c}\text { Mullin and Cook } \\
\left(\mathrm{x} \mathrm{10} 0^{-6} \mathrm{~cm}^{2} / \mathrm{s}\right)[5]\end{array}$ & $\begin{array}{c}\text { Hatfield,dkk } \\
\left(\mathrm{x} \mathrm{10} 0^{-6} \mathrm{~cm}^{2} / \mathrm{s}\right)[6]\end{array}$ & $\begin{array}{c}\text { Anand, dkk } \\
\left(\mathrm{x} \mathrm{10} 0^{-6} \mathrm{~cm}^{2} / \mathrm{s}\right)[7]\end{array}$ \\
\hline 0,4981 & $8,66 \pm 0,03$ & 8.65 & 8.50 & 8.75 & 8.55 \\
0,7469 & $8,09 \pm 0,07$ & 7.98 & 7.89 & 7.96 & 7.89 \\
0,9959 & $7,28 \pm 0,11$ & 7.27 & 7.30 & 7.35 & 7.22 \\
1,5471 & $6,70 \pm 0,06$ & 6.35 & 5.22 & 5.43 & 6.38 \\
1,9907 & $5,57 \pm 0,01$ & 5.52 & 5.30 & 5.55 \\
\hline \hline
\end{tabular}

difoto sebagai data $\mathrm{d}_{1}$, kemudian setelah berjalan 90 menit atau waktu-waktu tertentu sebagai data $\mathrm{d}_{2}$. Dengan cara yang sama dilakukan untuk berbagai konsentrasi larutan ammonium dihidrogen phosphate.

\section{HASIL DAN DISKUSI}

Penelitian ini menghasilkan 2 bentuk data, yaitu: data yang berupa gambar rumbai dan data yang bersifat kuantitatif. Data yang berupa gambar rumbai dapat dilihat pada Gambar 6.a, 6.b, 6.c, 6.d. Dari gambar tersebut, diolah menjadi data-data kualitatif yang tersaji pada Tabel 1 .

Foto dalam format JPEG dibuka dalam mikrosoft word, kemudian dilakukan pengkonversian dari luasan gambar dalam skala pixel diubah ke luasan $\mathrm{cm}$, agar didapatkan besar gambar sesuai ukuran aslinya. Setelah konversi didapatkan 7,13 $\mathrm{x} 10^{-5} \mathrm{~cm} /$ pixel, selanjutnya setiap gambar rumbai dianalisis untuk mendapatkan jarak pusat dua rumbai pada setiap gambarnya. Analisis tersebut dilakukan dengan cara menarik garis lurus pada pusat dua rumbai dengan memanfaatkan fasilitas "line" yang ada di Microsoft Word, hasilnya dicetak dan diukur dengan jangka sorong. Dalam penelitian ini masih digunakan alat jangka sorong, padahal penelitian-penelitian sebelumnya sudah mencapai proses pemrograman, hal ini karena penelitian ini baru merupakan langkah awal menentukan nilai koefisien difusi larutan transparan dengan menggunakan metode interferometer Michelson, diharapkan bila teknik ini berhasil maka bisa ditingkatkan dengan penyempurnaan menggunakan pemrograman borland delphi atau bahasa pemrograman yang lain.

Dari hasil penelitian ini diketahui bahwa untuk konsentrasi 0,4981; 0,7469; dan 0,9959 gmol/ $\ell$, nilai koefisien difusinya lebih mendekati pada literatur eksperimen yang dilakukan oleh Vani K. Chhanniwal[1], bila dibandingkan dengan literature dari Mullin and Cook [5], Hatfield [6], atau Anand [7]. Untuk konsentrasi 1,5471 gmol/ $\ell$ lebih mendekati literatur dari penelitian yang dilakukan oleh Hatfield, dan untuk konsentrasi 1,9907 gmol/ $\ell$ lebih mendekati literature penelitian yang dilakukan oleh Anand [7]. Hasil penelitian ini terdapat kesalahan relatif untuk konsentrasi $0,4981 \mathrm{gmol} / \ell$ sebesar $1,15 \%$, konsentrasi 0,7469 gmol/ $\ell$ sebesar $1,37 \%$, dan untuk konsentrasi $0,9959 \mathrm{gmol} / \ell$ sebesar $0,14 \%$. Sedangkan untuk konsentrasi 1,5471 gmol/ $\ell$ kesalahan relatif sebesar 5,5\% dan untuk konsentrasi 1,9907 gmol/ $\ell$ sebesar $0,91 \%$.

Berdasarkan data beserta analisis data dan perhitungan data yang telah dilakukan, maka hasil penelitian yang dilakukan dengan metode interferometri Michelson ini dapat digunakan untuk menentukan nilai koefisien difusi larutan transparan. Sensor CCD yang ada pada kamera digital dapat digunakan sebagai alat alternatif untuk mengamati perbedaan lintasan optis karena perbedaan konsentrasi pada waktu-waktu tertentu seperti yang ditunjukkan pada Gambar 6. Jika dibandingkan dengan pengukuran koefisien difusi larutan dengan metode interferometri holografi, maka metode ini lebih efisien dari segi waktu karena tidak membutuhkan kerja laboratorium yang maksimal seperti set up interferometer holografi. 


\section{SIMPULAN}

Berdasarkan hasil analisis dari data penelitian dan hasil pengamatan dapat diambil kesimpulan sebagai berikut:

1. Teknik Interferometer Michelson dapat digunakan untuk menentukan nilai koefisien difusi larutan transparan sistem ammonium dihidrogen phosphate $\left(\mathrm{NH}_{4}\right) \mathrm{H}_{2} \mathrm{PO}_{4}$.

2. Sensor CCD pada kamera digital dapat digunakan untuk mengamati perbedaan lintasan optik yang disebabkan karena perbedaan konsentrasi pada waktuwaktu tertentu $\left(\mathrm{t}_{1}\right.$ dan $\left.\mathrm{t}_{2}\right)$.

3. Nilai koefisien difusi larutan transparan yang dihasilkan dalam penelitian ini sesuai dengan literature dari Vani K. Chhaniwal [1] untuk konsentrasi 0,4981 gmol/ $\ell$ dengan kesalahan relatif $1,15 \%$, konsentrasi $0,7469 \mathrm{gmol} / \ell$ dengan kesalahan relatif 1,37\%; dan untuk konsentrasi $0,9959 \mathrm{gmol} / \ell$ dengan kesalahan relatif $0,14 \%$. Sedangkan untuk konsentrasi $1,5471 \mathrm{gmol} / \ell$ lebih mendekati literature dari Hatfield dengan kesalahan relatif 5,5\% dan untuk konsentrasi $1,9907 \mathrm{gmol} / \ell$ hasilnya lebih mendekati literature dari Anand [7] dengan kesalahan relatif sebesar $0,91 \%$.

4. Metode interferometer Michelson dapat digunakan sebagai metode alternatif untuk mendapatkan nilai koefisien difusi larutan transparan. Berdasarkan hasil penelitian yang diperoleh dari penelitian ini, dapat menunjukkan adanya perbedaan beda lintasan optis pada waktu-waktu tertentu, yang tidak bisa diamati pada metode interferometri holografi konvensional.

Berdasarkan hasil penelitian, maka bagi peneliti yang berminat untuk melanjutkan penelitian ini disarankan untuk:

1. Menggunakan sistem yang bisa merekam perubahan rumbai selama proses difusi berlangsung secara on-line dan real time

2. Membuat pemrograman dengan bahasa borland delphi atau lainnya, untuk menganalisa perbedaan beda lintasan optis pada waktu-waktu tertentu secara on-line dan real time, untuk memudahkan analisis hasil.
[1] Chhaniwal V.K, Anand Arun, Narayanamurthy, Optics and Lasers in Engineering, 42, 9-20 (2004)

[2] Apsari, R., Trisnaningsih, Analisis Koefisien Difusi Sistem Terner dari Rekonstruksi Hologram Lepas Sumbu Dengan Program Simulasi Komputer, Jurnal Penelitian Medika Eksakta, 4, No. 1, Surabaya (2003)

[3] Apsari, R., Pendayagunaan Sensor CCD untuk Otomasi Analisis Koefisien Difusi Sistem Isotermal Terner, Jurnal Penelitian Medika Eksakta, 3 No. 2, Indonesia (2002)

[4] Apsari, R dan Rachmaniah, Image Processing From Hologram
Reconstruction For Analysis Of Solution Diffusion Coefficient With Delphi, Pros. Seminar Nasional Basic Science II tanggal 26 Februari 2005. Malang (2005)

[5] Mullin JW, Cook TP., J.Appl.Chem. 13 (8): 423-429 (1963)

[6] Hatfield JD, Edwards OW, Dunn RL., J.Appl.Chem. 70 (8): 2555-2561 (1966)

[7] Anand A, Chhaniwal VK, Mukherjee S, Narayanamurthy CS., Opt.Laser Technology 34 (1): 45-49 (2002) 